\title{
INFLUENCE OF AIRLINES' SIZE AND LABOUR COSTS ON PROFITABILITY
}

\author{
Matías GINIEIS (D)*, Ana Beatriz HERNÁNDEZ-LARA (D), María Victòria SÁNCHEZ-REBULL \\ Department of Business Management, Faculty of Business and Economics, Universitat Rovira $i$ Virgili, Av. \\ Universitat, 1, (43204) Reus (Tarragona), Spain
}

Received 15 October 2019; accepted 29 January 2020

\begin{abstract}
It is important to examine profitability in the aviation sector and the factors that may affect it, due to their relevance for the airlines' survival. The main purpose of this paper is to analyse the effect of three internal business characteristics, namely labour costs, labour productivity and company size, on airlines' profitability, considering the airline type as a moderating effect. We have collected data of 190 European airlines during a 10-year period (2004-2013) which allowed us to create an unbalanced panel of 1,364 observations. Four types of airlines are considered. Results show that cost per employee has a positive influence on economic performance, especially for major carriers and regional carriers. It is also confirmed that the carrier type influences the relationship between labour costs, labour productivity and company size on the one hand, and economic returns on the other. These findings are relevant as they improve our understanding of economic profitability in different airlines' types.
\end{abstract}

Keywords: aviation, profitability, costs, airlines, labour productivity, economic performance.

\section{Introduction}

Across the years, the airline industry has been the subject of numerous studies in the academic literature. These have adopted different perspectives with respect to airline management (Ginieis, Sánchez-Rebull, \& Campa-Planas, 2012). Several investigations have shown that air transport is a significant contributor to the economic, social, environmental impacts and cultural development of a country (Reynolds-Feighan, 2001; Soria-Baledón \& Kosoy, 2018; Mohammadi-Amin \& Karimi, 2018). The growth rates of air traffic and gross domestic product (GDP) are positively associated (Chin \& Tay, 2001). The global air transport industry is still increasing and, in 2014, accounted for 63 million jobs and made a contribution of USD 2.7 trillion (3.5\%) to global GDP (ATAG, 2014, 2016). Over the last 55 years, the air transport industry has an average annual growth rate equal to almost $10 \%$, three times that of GDP (Oleshko \& Heiets, 2018).

In 2015, more than 3.5 billion passengers used air transport, an increase of $6.4 \%$ on the previous year when there were 34 million flights (Novak, et al., 2019). In Europe, the airline industry was responsible for the direct employment of over 2.5 million people in 2014, and its contribution to this region's GDP was around 192.8 billion USD. Considering the overall economic impact of aviation (direct, indirect, induced and tourism catalytic), European job creation would have been around 11.9 million jobs, and the sector's contribution to GDP around USD 860 billion (ATAG, 2016). In addition, in terms of infrastructure, airports have significantly contributed to their local economies (Button, 2003). The economic activity fostered by air transport is linked to economic growth, technological development, current globalization and the reduction of trade barriers between countries.

Over the last five years, global airline profitability has improved. These performance improvements are primarily caused by the industry consolidation and the restructuring strategies applied worldwide (Lopes et al., 2016). For example, in 2015, airlines generated an overall aggregate profit of USD 35.3 billion, primarily concentrated in North America (USD 22.9 billion) (IATA, 2016). A possible reason for these results relates to the higher profit margins in the airline industry due to lower fuel prices, increased passenger demand, significant appreciation of the US dollar and more seats occupied on flights (high load factors), as well as lower capital costs. The increase in

*Corresponding author. E-mail: matias.ginieis@urv.cat 
the airlines' profitability has been also related to outsourcing (for example to low cost carriers).

Profitability is an important factor in any company's survival, and airlines are no exception. Many airlines have been forced to undertake significant restructuring strategies in order to reverse declining profits, by improving productivity and efficiency (Oum \& Yu, 1998). However, although numerous studies have tried to explain company profitability, the main factors that influence this variable remain unconfirmed. In the air transportation sector, authors like Alamdari and Morrell (1997) have shown that the operating costs that airlines are subject to, and which affect profits, are influenced by both, by input prices (e.g. fuel costs, labour costs, airport taxes, etc.) and by operational characteristics pertinent to the airline type or model (e.g., a full service carrier (FSC), low cost carrier (LCC) or charter carrier $(\mathrm{CHC})$ or, short, medium or long distance carriers).

The significant economic contribution of the airline industry, the inconclusive results of previous research on the factors that affect its profitability, the considerable inhomogeneity and the diversity of business models applied by airlines, all justify the interest of academia on this topic. The main issue analysed in the present study is the influence of employee costs and the size of different types of airlines on profitability. We seek to provide further empirical evidence on several internal variables affecting airline profitability, including labour costs and airline size, while taking into consideration differing airline types and business models.

\section{Theoretical framework}

Previous researches have studied the determinants of companies' profitability. These determinants can be classified as either external or internal factors. The former are related to the geographical area where companies are located and include the economic situation of the country, the characteristics of their industrial sector, market competition and market share (Schmalensee, 1985; Caloghirou et al., 2004; Ambrosius et al., 2016; Shen, 2017).

Regarding the airline industry, two external factors have especially attracted the attention of academics, the liberalization and deregulation of the aviation industry, and the zone or region where airlines are located. Prior to the liberalization of the sector, expectations were that airlines would attain higher profits (Oum \& Yu, 1995, 1998). However, after deregulation, many airlines had to cope with increased pressure and competitiveness (Kalemba \& Campa-Planas, 2019). Research by Sjögren and Söderberg (2011) shows that, overall, deregulation increased airline productivity, and consequently profitability, however this effect is not clear for those belonging to strategic alliances. A second well-researched external factor affecting profitability is the zone or region where an airline is located. Some studies find that European airlines, on average, have a higher level of profitability (measured in terms of the rate of return on assets) than airlines in North America and Asia (Lee \& Hooy, 2012).

The internal factors considered most relevant for the airline industry are based, firstly, on inter-firm heterogeneity, for example airlines size or cost structure, and secondly on the airlines' competitive strategies, such as their organizational models. Internal factors that influence profitability related to the company itself (Rumelt, 1991; Merkert \& Pearson, 2015) include costs, labour productivity, company size, product characteristics, working capital, investments, assets, human resources, ownership and composition of corporate governing bodies, services quality, organization, strategies, etc. Clearly, there are numerous external and internal factors which need to be considered. Several studies have addressed the issue of the importance of an airline's costs. Gillen and Lall (2004), Tsoulakas et al., (2008), Berrittella et al., (2009), Link et al. (2009), Maenhout and Vanhoucke (2011) determined that, for both traditional airlines and LCCs, fuel and staffing are the largest cost items. Tsoulakas et al. (2008) arrived at the same conclusion and claimed that together they represent approximately $50 \%$ of their overheads. Likewise, Doganis (2001) identified labour costs as one of the three critical areas that allow for cost reductions and consequent profitability increases in airlines.

Previous analysis shows that labour costs in the airline industry are closely linked to the business model applied. Several researches have shown that LCCs pay their employees less than do other airlines. Dobruszkes (2006) found that, despite having a greater workload, LCC staff are paid less than their counterparts in FSC companies. Similarly, Barkin et al. (1995) showed that, as compared to traditional airlines, LCCs in the US aviation market manage to save between 10 and 20\% in personnel costs. A study by Najda (2003) claims that LCCs such as Southwest and JetBlue Airways have labour costs that are about $30 \%$ to $40 \%$ lower than those of traditional companies.

The second key internal factor under consideration is size. The formation of networks, fusions and alliances is an important feature of the sector, and affects the airlines' size (Oum et al., 2004). Airlines have constant investment needs and must keep their technology updated. There is an ongoing need for financial and human capital. This explains the high financial risks that affect their profitability (Capobianco \& Fernandes, 2004). Literature on the subject indicates that larger size implies more available resources and also higher returns through economies of scale, synergies, greater strength in negotiating with suppliers and customers (Fariñas et al., 1992; Galve \& Salas, 1993; González \& Correa, 1998). These benefits would explain the proliferation of networks and strategic alliances within the sector.

Considerable research has been carried out on the relationship between the type or model of airline and its profitability. The results of the estimated cost model of different airline types proposed by Hansen et al. (2001) confirm the anticipated relationship between airline performance and its business model. These authors studied ten domestic 
airlines in the US, and their results demonstrated that the business model explains flight delays, arising from disorganization and irregularity, and the cost structure for those airlines investigated.

Internal factors are also highly relevant since the company can manage them. Rumelt (1991) states that firm/ business unit effects (internal factors) are more important than industry effects (external factors). In fact, previous research has tended to focus on internal factors, especially labour costs and productivity, and airlines' size, which are relevant to determining the competitive position of companies through their strategies and business models. Given the relevance of internal factors in explaining profitability in the airline industry, this work has a two-fold purpose:

1. it analyses and explains the direct relationship that exists between two internal characteristics of the airline (cost per employee and the size of the company) and the influence they exert on the economic profitability of the airline and,

2. the differences between these relationships are observed when comparing different types of airlines.

In this study, the personnel costs of European airlines are examined in order to have an understanding of the influence this variable may have on profitability in different types of airlines in Europe.

The paper is structured as follows. The next section outlines the methodology, describes the data gathering process, the measurement of the variables, and the analysis. Section 3 contains the results and the final section presents and discusses our main research conclusions.

\section{Methodology}

\subsection{Data collection}

To conduct this research, data for 190 European airlines over a period of ten years (2004-2013) were collected. This resulted in an unbalanced panel of 1,364 observations. The start year of 2004 was chosen because the Amadeus database then began publishing the financial statements of almost all the world's airlines.

Since the Amadeus database is one of the most relevant and used databases for the collection of financial and economic data from European companies, it was our primary source.

The airlines included in our sample fulfilled the following requirements:

- They had received favourable external audits during the period under consideration;

- They were required to present their individual financial statements every year;

- They were active companies.

\subsection{Measuring the variables}

The dependent variable of this study was the economic profitability of European airlines. This variable was measured using two different indicators (Campa-Planas et al.,
2011; Hernández et al., 2012). The first, economic profitability (EP1), was calculated as the percentage of operating results or earnings before interests and taxes (EBIT) from total company assets. The second, economic profitability ratio (EP2), was measured by dividing the EBIT by the average number of employees.

The first explanatory variable of this work was the unit cost per employee (CE) which has been used by numerous academics making comparative studies within the airline industry (Oum \& Yu, 1995; 1998; Fernandes \& Capobianco, 2001; Gudmundsson, 2004, Oum et al., 2005; Greer, 2008; Heracleous \& Wirtz, 2009, Melo Filho et al., 2014). It is calculated by dividing the total costs for employees each year by the total number of staff employed in the same year.

Our second explanatory variable was the company size. We considered it appropriate to choose two different size indicators; the average number of employees (EMP) and the total assets (TA) (Campa-Planas et al., 2011; Hernández et al., 2012), both of them highly related to company's size in different economic sectors, and specifically in the airline industry (Heshmati \& Kim, 2016).

This study also included the moderating effect of the categorical variable used to identify the airline type (TYPE). To categorize the different types of airlines, we mainly followed the guidelines proposed by Ginieis et al. (2013) but took into account a division in FSCs which necessitated adding another category. We included two FSCs subtypes: major carriers (MJCs) and regional carriers (RECs). Finally, we considered four different airline types: CHCs, LCCs, MJCs and RECs using a four-level categorical variable.

In our categorization, mayor carriers (MJCs), included long-distance companies, airlines with a fleet of wide-bodied aircraft. Here we included flag carriers or traditional airlines (Lufthansa, Air France, British Airways, Iberia, etc.) and regular or legacy carriers (Virgin Atlantic Airways, Thomas Cook Airlines, Air Europa, etc.). MJC are usually members of strategic alliances in which partners require their members' commitment (Klophaus, 2005). They provide a higher level of service than low cost carriers (LCCs) (de Neufville, 2008; Neal, Kassens-Noor, 2011; Tretheway, 2011), especially during the flight (for example, food service and on-board entertainment). They usually offer first class or business class seats.

LCCs are different from conventional airlines and their business model is very simple (Srisaeng et al., 2014). They implement strategies to reduce costs such as using secondary airports because these tend to have lower airport charges (Pantazis \& Liefner, 2006; Albers et al., 2010) and operate point-to-point systems. They reduce any "unnecessary" costs, such as claims for baggage loss (Graf, 2005) and operate a fleet of a single aircraft type, so they save on pilot and cabin crew training (Mason, 2000).

Regional carriers (RECs) are those that operate only in regional area flying only within a comparatively small geographical area (Halpern, 2008) and providing an air 
transportation service to communities with limited demand (Santana, 2009). Examples of RECs are the "feeder" companies of a flag-carrier or regular airlines.

An Air Charter Service (henceforth, CHC) does not market its services through the usual sales channels (Randøy \& Strandenes, 1997). CHCs operate flights outside the usual scheduled times. Their flights are operated by contractual agreements with specific clients, or they are associated with specific tour operators (Halpern, 2008). Most regular airlines also occasionally provide charter services if they have spare capacity.

Finally, although the focus of this research is on airlines size and their labour costs, other variables exert impacts on profitability, some of them being specific of the airline industry as previously mentioned in the literature review. We decided to include some of them in our models to avoid problems of omitted variables, specifically fuel costs (FC) and labour productivity (LP).

Previous researches have established a relevant and negative influence of FC on profitability (Carter et al., 2003; Morrell, 2005). Carter et al. (2003) suggest that the cost of fuel is an important expense for any airline and has a significant impact on the profitability. Morrell (2005) indicates that the fuel is the second most significant cost for airlines, so it is important to control it. FC information has been collected from the airlines' Annual Reports for the years under study.

We also included a labour productivity indicator (LP), the operating revenue per employee. It allows us to estimate how much the employees contribute to the total operating income of the airlines and thus it is a measure of their performance. Jakšić et al., (2012) explain that there is a direct linear relationship between operating revenue and the number of employees, which means that more employees contribute to achieving greater operating revenue. The impact of productivity on profitability has been studied by diverse authors (Stierwald, 2010) and, in the specific case of the airline industry, several studies have found that productivity is a significant determinant of profitability (Mantin \& Wang, 2012). Among different measures of productivity, labour productivity emerges as a relevant type due to its influence on the global productivity of the airline industry (Barbot et al., 2008; Parast \& Fini, 2010).
All numeric variables were log-transformed to avoid problems with skewness and linearize their distributions. Standardized variable values were used in our analyses.

\section{Results and discussion}

We firstly undertook descriptive statistical tests and examined the correlation between variables. An ANOVA analysis was performed to evaluate the degree of association (or independence) between the variables. These analyses were complemented by performing multicollinear diagnoses to uncover any problems in the regressions. Model adequacy was analysed, and residual analysis diagnostics undertaken to confirm the efficiency of the model parameters following the steps pointed out by Tesfay and Solibakke (2015) and Tesfay (2016a, 2016b). Finally, a regression analysis estimated the relationships between the variables studied.

Table 1 shows the descriptive statistics and correlation matrix for the numerical variables. High correlations between some explanatory variables included in the same model can be observed. Besides, there was a high correlation between the two ratios of economic profitability, which suggests the suitability of analysing two different models, one for each of the indicators of economic profitability, thus gaining greater robustness in the results obtained. There was also correlation between the two independent variables that measure company size, but we decided not to include both of them in the same model, so the measurement of company size used in both models was different. Our multicollinearity diagnostics did not reveal any problems in the regressions. Every independent variable included in each model captured a relevant proportion of the variance. Variance inflation factor (VIF) analyses were conducted for each model, showing maximum values below the upper bound of 10 , which suggests the absence of unacceptable multicollinearity.

For the categorical variables, such as airline type, the percentage of companies in each of these categories was calculated. Our sample indicated that $\mathrm{CHCs}$ represented $45.4 \%$ of the data, LCCs $7.5 \%$, MJCs $21.8 \%$, and RECs $25.3 \%$.

We noted that, according to the annual financial statements submitted by these companies during the 10-year period under study (2004-2013), MJCs are the type with the

Table 1. Descriptive statistics and correlation matrix

\begin{tabular}{|c|c|c|c|c|c|c|c|c|c|}
\hline Variables & mean & SD & Log EP1 & Log EP2 & $\log C E$ & $\log \mathrm{TA}$ & Log EMP & $\log C F$ & Log LP \\
\hline Log EP1 & -3.022 & 1.338 & 1 & & & & & & \\
\hline Log EP2 & 9.228 & 1.624 & $0.760^{\star * *}$ & 1 & & & & & \\
\hline $\log C E$ & 10.628 & 0.883 & 0.020 & $0.366^{* * *}$ & 1 & & & & \\
\hline $\log \mathrm{TA}$ & 17.822 & 2.096 & $-0.155^{\star * *}$ & $0.141^{\star * *}$ & $0.274^{\star \star \star}$ & 1 & & & \\
\hline Log EMP & 5.667 & 1.948 & $-0.115^{\star * *}$ & $-0.163^{\star * *}$ & 0.005 & $0.848^{\star * *}$ & 1 & & \\
\hline $\log \mathrm{FC}$ & 12.635 & 1.095 & 0.046 & $0.224^{*}$ & 0.114 & $0.871^{\star * *}$ & $0.837^{\star * *}$ & 1 & \\
\hline Log LP & 19.346 & 1.929 & $0.139^{\star * *}$ & $0.550^{* * *}$ & $0.669^{* * *}$ & $0.143^{\star * *}$ & $-0.214^{\star * *}$ & 0.104 & 1 \\
\hline
\end{tabular}

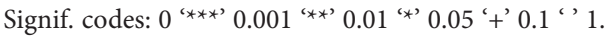


largest proportion of labour costs per operative revenues (approximately 24\%), followed by the RECs (almost 20\%), CHCs (around 14\%) and LCCs (around 12\%) (see Figure 1).

We conducted analyses of variance in order to determine whether some significant differences could be seen between companies of different types. Although it was not an objective of this investigation, we considered it appropriate to conduct prior exploratory analyses that determine differences among airline types in order to later justify the explanatory models used in this research. This is due to the expected impact that the airline type could exert on the effects of labour costs and airline size over profitability. The following tables and figures show the most relevant results.

Tables 2 and 3 (Figures 2,3) show that the mean values of economic profitability were significantly different when comparing airline types. MJCs present the lowest mean values for both types of economic profitability, whilst

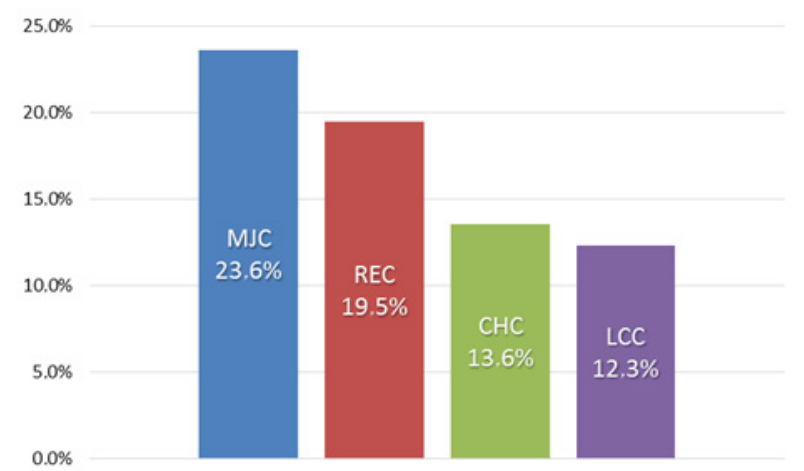

Figure 1. Personnel costs in terms of operating revenue for airline type (source: created by the authors)

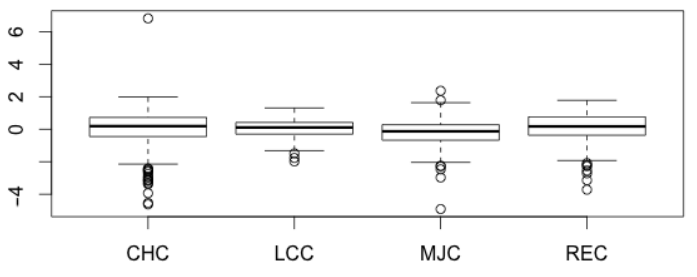

Figure 2. Boxplot for EP1 by company type (source: created by the authors)

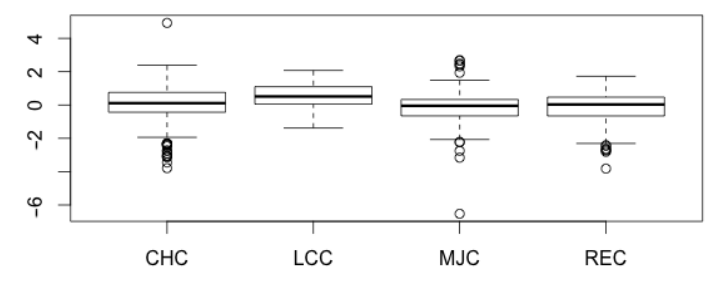

Figure 3. Boxplot for EP2 by company type (source: created by the authors)

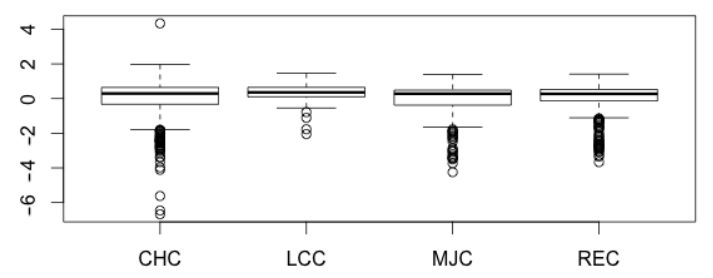

Figure 4. Boxplot for CE by company type (source: created by the authors)

Table 2. ANOVA analysis for EP1

\begin{tabular}{|l|c|c|c|c|c|c|c|c|c|}
\hline \multirow{2}{*}{ Variable } & \multicolumn{2}{|c|}{ CHC } & \multicolumn{2}{c|}{ LCC } & \multicolumn{2}{c|}{ MJC } & \multicolumn{2}{c|}{ REC } & ANOVA \\
\cline { 2 - 10 } & mean & SD & mean & SD & mean & SD & mean & SD & F \\
\hline Log EP1 & 0.041 & 1.084 & 0.018 & 0.678 & -0.221 & 0.917 & 0.079 & 0.942 & $3.349^{*}$ \\
\hline
\end{tabular}

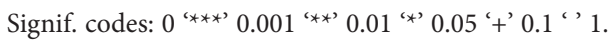

Table 3. ANOVA analysis for EP2

\begin{tabular}{|c|c|c|c|c|c|c|c|c|c|}
\hline \multirow{2}{*}{ Variable } & \multicolumn{2}{|c|}{ CHC } & \multicolumn{2}{c|}{ LCC } & \multicolumn{2}{c|}{ MJC } & \multicolumn{2}{c|}{ REC } & ANOVA \\
\cline { 2 - 10 } & mean & SD & mean & SD & mean & SD & mean & SD & F \\
\hline Log EP2 & 0.033 & 1.005 & 0.510 & 0.741 & -0.134 & 1.069 & -0.113 & 0.954 & $7.57^{* * *}$ \\
\hline
\end{tabular}

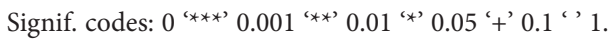

Table 4. ANOVA analysis for CE

\begin{tabular}{|l|c|c|c|c|c|c|c|c|c|}
\hline \multirow{2}{*}{ Variable } & \multicolumn{2}{|c|}{ CHC } & \multicolumn{2}{c|}{ LCC } & \multicolumn{2}{c|}{ MJC } & \multicolumn{2}{c|}{ REC } & ANOVA \\
\cline { 2 - 10 } & mean & SD & mean & SD & mean & SD & mean & SD & F \\
\hline Log CE & 0.002 & 1.085 & 0.334 & 0.540 & -0.093 & 0.976 & -0.022 & 0.948 & $4.739^{* *}$ \\
\hline
\end{tabular}

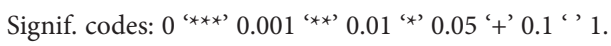


RECs exhibit the highest mean value for EP1, and LCCs the highest mean value for EP2.

These results show that the assets of RECs generate higher income than other airline types (see EP1). Larger airlines, such as MJCs show lower averages. In EP2, we see that LCCs employees are the most productive of all types, whereas the employees of the MJCs are the least productive.

In terms of the first explanatory variable, unit cost per employee (CE), Table 4 and Figure 4 show significant differences in their mean value when comparing different types of airlines, being the highest in the case of LCCs and the lowest for MJCs.

We have provided two possible explanations to this somewhat controversial result. First, in this study we have considered the cost of staff in general, instead of the employees' basic wage. LCCs have fewer personnel than traditional airlines, but their staff work more hours, which means that they pay them overtime and other allowances, and this might affect the final results of this research. Another possible explanation is that we compared the costs for employees without discriminating between labour categories - in the MJCs there are more labour categories and higher wages gaps between employees. Furthermore, our dataset contains only a few LCCs from Eastern Europe, while there are many airlines of other types (MJCs, RECs and CHCs) in Russia, Ukraine, Romania and Bulgaria. This also may affect average labour costs when comparing region by region.

The results for company size are shown in the following tables and figures.

When reviewing the results for the measurements of company size (Tables 5, 6 and Figures 5, 6), some relevant and significant differences can be observed when comparing different airlines types. MJCs and LCCs exhibit higher mean values in terms of company size (considering both

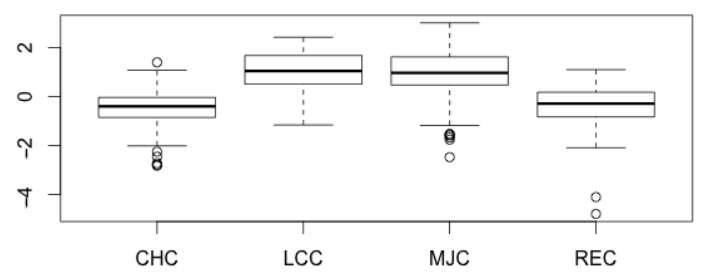

Figure 5. Boxplot for TA by company type (source: created by the authors)

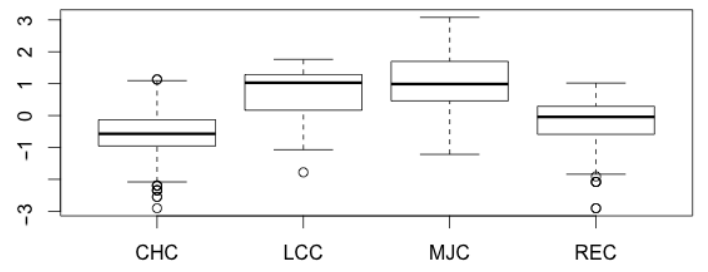

Figure 6. Boxplot for EMP by company type (source: created by the authors)

total assets and employee numbers) when compared to RECs and CHCs.

This can be explained as follows. LCCs and MJCs have fleets with long-haul aircraft and large fuselage width (and modern fleets, in the case of LCCs), which increase their asset values. However, the aircrafts used by RECs or CHCs, which are normally used for short-haul flights, are smaller. So, when compared to other airlines with larger aircraft, their assets are of a lower value. With regard to the EMP variable, MJCs are assumed to have higher staff numbers with respect to CHCs.

The results for the fuel costs are displayed in Table 7 and Figure 7.

Table 5. ANOVA analysis for TA

\begin{tabular}{|l|c|c|c|c|c|c|c|c|c|}
\hline \multirow{3}{*}{ Variable } & \multicolumn{2}{|c|}{ CHC } & \multicolumn{2}{c|}{ LCC } & \multicolumn{2}{c|}{ MJC } & \multicolumn{2}{c|}{ REC } & ANOVA \\
\cline { 2 - 10 } & mean & SD & mean & SD & mean & SD & mean & SD & F \\
\hline Log TA & -0.465 & 0.619 & 1.039 & 0.845 & 0.994 & 0.976 & -0.327 & 0.757 & $330^{* * *}$ \\
\hline
\end{tabular}

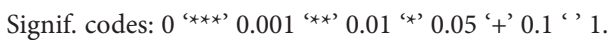

Table 6. ANOVA analysis for EMP

\begin{tabular}{|l|c|c|c|c|c|c|c|c|c|}
\hline \multirow{2}{*}{ Variable } & \multicolumn{2}{|c|}{ CHC } & \multicolumn{2}{c|}{ LCC } & \multicolumn{2}{c|}{ MJC } & \multicolumn{2}{c|}{ REC } & ANOVA \\
\cline { 2 - 10 } & mean & SD & mean & SD & mean & SD & mean & SD & F \\
\hline Log EMP & -0.557 & 0.650 & 0.744 & 0.758 & 1.109 & 0.903 & -0.174 & 0.719 & $383.1^{* * *}$ \\
\hline
\end{tabular}

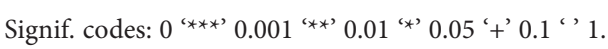

Table 7. ANOVA analysis for FC

\begin{tabular}{|l|c|c|c|c|c|c|c|c|c|}
\hline \multirow{2}{*}{ Variable } & \multicolumn{2}{|c|}{ CHC } & \multicolumn{2}{c|}{ LCC } & \multicolumn{2}{c|}{ MJC } & \multicolumn{2}{c|}{ REC } & ANOVA \\
\cline { 2 - 10 } & mean & SD & mean & SD & mean & SD & mean & SD & F \\
\hline Log FC & -1.424 & 0.851 & 0.076 & 0.452 & 0.345 & 0.875 & -1.805 & 0.606 & $53.21^{* * *}$ \\
\hline
\end{tabular}

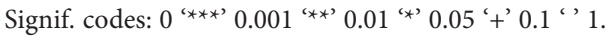




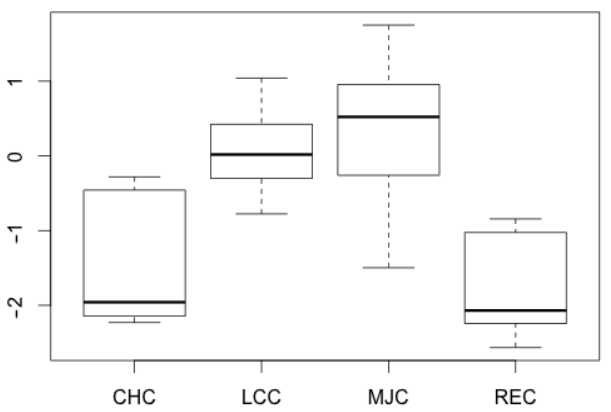

Figure 7. Boxplot for FC by company type (source: created by the authors)

Table 7 and Figure 7 show some relevant and significant differences in terms of fuel costs when comparing different airlines types. MJCs and LCCs exhibit higher mean values than RECs and CHCs, but MJCs are the type with the highest fuel costs.

According to our results, RECs and CHCs have managed to protect themselves from the constant changes in fuel prices and have obtained lower fuel costs than larger companies such as the MJC and LCC. This finding is noteworthy and deserves to be further studied because the study carried out by the European Cockpit Association (ECA, 2006), indicates that CHCs are amongst the most affected airlines when compared to LCCs and MJCs since, in the short term, they are not able to react to fuel price changes.

Finally, the results for labour productivity (LP) are shown in Table 8 and Figure 8.

The results of Table 8 and Figure 8 show significant differences in the mean values of labour productivity when comparing different types of airlines. According to our results, LCCs are the airlines with higher labour productivity.

Following on this exploratory analysis and given that the database combines observations of airlines across time, panel data methodology was used in the estimation process. We conducted random effects regression analyses as suggested by the results of the Durwin-Wu-Hausman test (Table 9). We also included time dummies in the panel regression models.

For the purpose of this study, in which we have tried to determine, on the one hand, the influence of costs per employees and company size on economic profitability in the airline sector, and on the other, the possible differences that can be expected between these effects, depending on airline types, we considered it appropriate to specify two

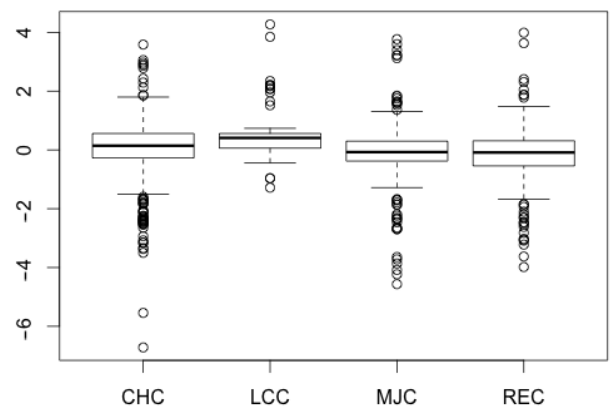

Figure 8. Boxplot for LP by company (source: created by the authors)

models. Each model involves a different measurement of economic profitability.

In the first model, where the dependent variable was EP1 (EBIT/TA), company size was determined by means of the number of employees. In the second model, where the dependent variable was EP2 (EBIT/EMP), we included total assets as one of the explanatory variables.

To investigate whether airline type would strengthen or weaken the effect of cost per employee and company size on economic profitability, the following moderated regression equations were utilized:

$$
\begin{aligned}
& E P 1 i t=\beta 0+\beta 1 \text { Year }+\beta 2(F C) i t+\beta 3(L P) i t+ \\
& (\beta 4(C E) i t+\beta 5(E M P) i t) \cdot T Y P E i t+i t ; \\
& E P 2 i t=\beta 0+\beta 1 Y e a r+\beta 2(F C) i t+\beta 3(L P) i t+ \\
& (\beta 4(C E) i t+\beta 5(T A) i t) \cdot \text { TYPE it }+i t .
\end{aligned}
$$

As mentioned above, to analyse the adequacy and diagnosis of the model through residual analysis and to confirm the efficiency of the model parameters, we followed the steps described by Tesfay and Solibakke (2015) and Tesfay (2016a, 2016b). Firstly, we computed the estimated residuals. Then, we applied the Ljung-Box test of serial autocorrelation on the estimated residuals for both models. We did not reject the null-hypotheses because autocorrelations were small and non-significant (Ljung-Box Q Chi-Sq $=24.962, p$-value $=0.1618$ for EP1; Ljung-Box $\mathrm{Q}$ Chi-Sq $=23.841, p$-value $=0.1823$ for EP2). These results imply that the models fit can be considered free from autocorrelation problems.

Results from Table 9 confirm the influence of costs per employee on economic profitability. The influence is positive and significant in both models $(\beta=2.605$; $p$-value $<0.01$ for EP1, and $\beta=1.568$; $p$-value $<0.05$ for EP2). Regarding size, effects were only significant in

Table 8. ANOVA analysis for LP

\begin{tabular}{|l|c|c|c|c|c|c|c|c|c|}
\hline \multirow{2}{*}{ Variable } & \multicolumn{2}{|c|}{ CHC } & \multicolumn{2}{c|}{ LCC } & \multicolumn{3}{c|}{ MJC } & \multicolumn{3}{c|}{ REC } & ANOVA \\
\cline { 2 - 11 } & mean & SD & mean & SD & mean & SD & Mean & SD & F \\
\hline Log LP & 0.067 & 0.999 & 0.474 & 0.812 & -0.143 & 1.056 & -0.137 & 0.949 & $12.95^{\star * *}$ \\
\hline
\end{tabular}

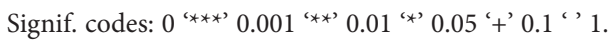


Table 9. Results of the random effects regression analyses

\begin{tabular}{|c|c|c|c|c|}
\hline \multirow{2}{*}{ Variables } & \multicolumn{2}{|c|}{ Model 1 (Dependent variable EP1) } & \multicolumn{2}{|c|}{ Model 2 (Dependent variable EP2) } \\
\hline & $\mathrm{B}$ & Std. Error & B & Std. Error \\
\hline Intercept & 0.336 & 0.592 & 0.125 & 0.548 \\
\hline Year 2005 & -0.144 & 0.306 & -0.095 & 0.251 \\
\hline Year 2006 & -0.505 & $0.278+$ & -0.447 & $0.231+$ \\
\hline Year 2007 & -0.020 & 0.260 & -0.060 & 0.214 \\
\hline Year 2008 & -0.041 & 0.293 & -0.079 & 0.248 \\
\hline Year 2009 & -0.333 & 0.277 & -0.321 & 0.232 \\
\hline Year 2010 & -0.274 & 0.293 & -0.248 & 0.246 \\
\hline Year 2011 & -0.367 & 0.283 & -0.347 & 0.242 \\
\hline Year 2012 & -0.356 & 0.285 & -0.316 & 0.245 \\
\hline Year 2013 & -0.099 & 0.278 & -0.109 & 0.241 \\
\hline FC & 0.080 & 0.238 & 0.089 & 0.222 \\
\hline LP & 0.254 & 0.208 & 0.674 & $0.140^{\star * *}$ \\
\hline $\mathrm{CE}$ & 2.605 & $0.918^{* *}$ & 1.568 & $0.617^{\star}$ \\
\hline EMP & 1.991 & $0.830^{*}$ & & \\
\hline TA & & & 0.626 & 0.848 \\
\hline LCC & -0.083 & 0.632 & -0.221 & 0.554 \\
\hline MJC & -0.199 & 0.438 & 0.001 & 0.429 \\
\hline REC & 0.499 & 0.811 & -0.050 & 0.533 \\
\hline $\mathrm{CE}^{\star} \mathrm{LCC}$ & -2.855 & $0.999^{\star *}$ & -1.628 & $0.698^{*}$ \\
\hline $\mathrm{CE}^{*} \mathrm{MJC}$ & -2.636 & $0.936^{* *}$ & -1.445 & $0.633^{*}$ \\
\hline $\mathrm{CE}^{\star} \mathrm{REC}$ & -1.929 & $1.107+$ & -1.968 & $0.825^{*}$ \\
\hline $\mathrm{TA}^{\star} \mathrm{LCC}$ & & & -0.320 & 0.851 \\
\hline $\mathrm{TA}^{\star} \mathrm{MJC}$ & & & -0.637 & 0.863 \\
\hline $\mathrm{TA}^{\star} \mathrm{REC}$ & & & 0.872 & 1.182 \\
\hline $\mathrm{EMP}^{\star} \mathrm{LCC}$ & -2.111 & $0.870^{\star}$ & & \\
\hline $\mathrm{EMP}^{\star} \mathrm{MJC}$ & -2.054 & $0.840^{*}$ & & \\
\hline $\mathrm{EMP}^{\star} \mathrm{REC}$ & -3.477 & $1.808+$ & & \\
\hline Hausman test & \multicolumn{2}{|c|}{6.122 (p-value 0.9976$)$} & \multicolumn{2}{|c|}{8.470 (p-value 0.9813$)$} \\
\hline Adjusted R-Squared & \multicolumn{2}{|c|}{0.167} & \multicolumn{2}{|c|}{0.379} \\
\hline $\mathrm{F}$ & \multicolumn{2}{|c|}{$1.572+$} & \multicolumn{2}{|c|}{$4.154^{\star * *}$} \\
\hline
\end{tabular}

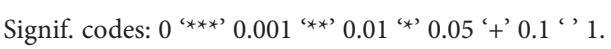

the case of the number of employees on EP1 ( $\beta=1.991$; p-value $<0.05$ ), meaning that a higher company size, in terms of number of employees, improves economic profitability, while a non-significant effect was found between total assets and EP2. These results refer to $\mathrm{CHC}$ airlines, which are the baseline of these analyses.

Regarding the airline type, non-significant effects were found in both models, which points out that the airline type, by itself, does not exert a significant effect on profitability.

The moderating effects of an airline's type on the relationship between CE and profitability were negative and significant in the case of LCC $(\beta=-2.855$; p-value $<0.01$ for EP1 and $\beta=-1.628$; $p$-value $<0.05$ for EP2). This implies that the positive effect proven between $\mathrm{CE}$ and profitability for $\mathrm{CHC}$, becomes negative for LCC. In the case of MJC, these moderating effects were also negative and significant in both models $(\beta=-2.636$; $p$-value $<0.01$ for EP1 and $\beta=-1.445$; $p$-value $<0.05$ for EP2), which also suggest a lower impact of $\mathrm{CE}$ on profitability when comparing MJC to CHC. This influence of CE even becomes negative on EP1 in MJC, and it is positive on EP2, but much lower when comparing MJC to CHC. In the case of REC, again, the moderating effects were negative and significant in both models $(\beta=-1.929$; $\mathrm{p}$-value $<0.1$ for $\mathrm{EP} 1$ and $\beta=-1.968$; $\mathrm{p}$-value $<0.05$ for EP2). These results mean that the influence of CE on EP1 is positive for REC but lower in comparison to $\mathrm{CHC}$, and negative in the case of EP2.

Finally, the moderating effects of the airline type on the relationship between the number of employees and EP1 were negative and significant for LCC $(\beta=-2.111$; 
$p$-value $<0.05)$, MJC $(\beta=-2.054 ; p$-value $<0.05)$ and REC $(\beta=-3.477 ; p$-value $<0.1)$. These results imply that the positive influence between the number of employees and EP1 proven for CHC $(\beta=1.991$; $p$-value $<0.05)$ becomes negative for other airline types. Non-significant effects were found in the relationships of total assets and EP2, when the moderating influence of the airline type is considered.

Regarding the rest of the variables included in our models, fuel cost and labour productivity, the results indicate non-significant influence of these variables on profitability, the only exception being of LP which has a positive and significant influence on EP2 ( $\beta=0.674 ; p$-value $<0.001)$. This means that airlines with a high labour productivity obtain high economic profitability measured in terms of the number of employees. The effect of time was not proven significant with our dataset.

\section{Conclusions}

On the one hand, our purpose was to explore the direct relationship that cost per employee and company size, as internal airline characteristics, exert on economic profitability in the sector. On the other hand, we were interested in discovering whether relevant differences could be observed in these relationships when comparing different airline types. The originality of this work is its analysis of two models including two different economic variables (profitability over assets and profitability per employee), while at the same time four types of airlines are compared.

The findings of this study underlined an influence of cost per employee on economic profitability for CHC. This effect was positive and independent of the way of measuring this profitability, much higher than for MJC and REC while was negative for LCC. Regarding the company size, only when measured by the number of employees, it was observed a positive relationship with economic profitability in the case of $\mathrm{CHC}$ carriers, implying that a higher number of employees in this airline type is related to higher economic profitability (as measured as EBIT divided by total assets). One possible explanation for these results is that $\mathrm{CHC}$ airlines in our dataset are mostly airlines that carry out executive and business flights. Therefore, they can better manage their costs and thus achieve greater profitability since they mainly work with previously booked flights, in which they can assure and increase their economic profitability even when their cost structure in terms of personnel and size are high. In this type of airlines, the influence of the airline size in terms of the number of employees on economic profitability is positive. On the contrary, in the other airline types, a lower size and also lower costs structures assure a better performance in terms of economic profitability. Nevertheless, further exploration of the possible reasons for the results obtained in this study will constitute an interesting research line for the future.

A direct influence was also observed in the case of labour productivity, which demonstrates the positive effect of labour productivity on economic performance, at least when measured as EBIT per employee. Thus, we may assert that an airline's economic profitability depends on the cost per employee, the airline's size and the labour productivity (although the level of influence of some of these variables is not the same for all types of airlines, being higher or lower depending on the type of airline under consideration). These important differences exhibited by different airline types confirm that the airline industry is not a homogenous sector, and the relevance of considering the potential impact of these differences exhibited by each airline type and its business model.

This research, nevertheless, has several limitations that might be addressed in the future. We have considered employee costs without discriminating between labour categories and we have not considered wage gaps among employees when comparing airlines in different geographical regions or countries. Also, studying labour costs in different geographical areas, while taking into account existing gaps and different national degrees of inflation, would be an interesting analysis to carry out in the future, as it would allow us to better explore the influence of these variables on profitability. Furthermore, although the ratios used in this study are the most commonly applied when measuring firms' profitability, other variables might also add valuable information to the characteristics and performance of airline companies. Another important limitation was the impossibility of showing with our dataset the significant influence of fuel cost on economic profitability established in earlier research. The inclusion of more airlines and years could provide more data and contribute to solving this problem in the future. Finally, the inclusion of additional explanatory variables, such as the number of fleet or the material costs, was considered in this study because of their potential influence on profitability. However, problems of multicollinearity were observed between several such explanatory variables when tested them in our models, and also the number of observations was reduced due to missing data issues.

Finally, we consider that this paper contributes to the existing literature responding to several relevant but previously unanswered questions in the airline industry, and provides a more in-depth understanding of economic profitability in the sector, which may be useful for further studies and for managers in the air transport sector. Specific insights are provided regarding the economic profitability of different types of carriers which adopt different business models, which aid in understand the effect of labour costs and airline size on economic profitability. 


\section{References}

Alamdari, F., \& Morrell, P. (1997). Airline labour cost reduction: post-liberalisation experience USA and Europe. Journal of Air Transport Management, 3(2), 53-66.

https://doi.org/10.1016/S0969-6997(97)00024-0

Albers, S., Heuermann, C., \& Koch, B. (2010). Internationalization strategies of EU and Asia-Pacific low fare airlines. Journal of Air Transport Management, 16(5), 244-250.

https://doi.org/10.1016/j.jairtraman.2009.12.001

Ambrosius, M., Grimm, V., Solch, C., \& Zottl, G. (2016). Investment incentives for flexible energy consumption in the industry. International Conference on the European Energy Market. EEM, Porto, Portugal. https://ieeexplore.ieee.org/ iel7/7514734/7521173/07521234.pdf

ATAG. (2014). Aviation benefits beyond borders. Powering global economic growth, employment, trade links, tourism and support for sustainable development through air transport. Air Transport Action Group (ATAG), Report, April 2014. https:// aviationbenefits.org/media/26786/ATAG_AviationBenefits2014_FULL_LowRes.pdf

ATAG. (2016). Aviation benefits beyond borders. Powering global economic growth, employment, trade links, tourism and support for sustainable development through air transport. Air Transport Action Group (ATAG), Report, July 2016. https:// aviationbenefits.org/media/149668/abbb2016_full_a4_web.pdf

Barbot, C., Costa, A., \& Sochirca, E. (2008). Airlines performance in the new market context: a comparative productivity and efficiency analysis. Journal of Air Transport Management, 14, 270-274. https://doi.org/10.1016/j.jairtraman.2008.05.003

Barkin, T. I., Hertzell, O. S., \& Young, S. J. (1995). Facing lowcost competitors: lessons from US airlines. The McKinsey Quarterly, 4(4), 86-99. https://www.questia.com/library/ journal/1G1-55427465/facing-low-cost-competitors-lessonsfrom-us-airlines

Berrittella, M., La Franca, L., \& Zito, P. (2009). An analytic hierarchy process for ranking operating costs of low cost and full service airlines. Journal of Air Transport Management, 15(5), 249-255. https://doi.org/10.1016/j.jairtraman.2008.11.006

Button, K. (2003). Does the theory of the "core" explain why airlines fail to cover their long-run costs of capital? Journal of Air Transport Management, 9(1), 5-14.

https://doi.org/10.1016/S0969-6997(02)00075-3

Caloghirou, Y., Protogerou, A., Spanos, Y. E., \& Papagiannakis, L. (2004). Industry-versus firm-specific effects on performance: contrasting SMEs and large-sized firms. European Management Journal, 22(2), 231-243.

https://doi.org/10.1016/j.emj.2004.01.017

Campa-Planas, F., Hernández-Lara, A. B., Sánchez-Rebull, M. V., \& Veses-Ibáñez, V. (2011). La rentabilidad económica explicada a través del tamaño. Las empresas de ingeniería civil en España. Dyna, 86(5), 549-556. https://doi.org/10.6036/4054

Capobianco, H. M. P., \& Fernandes, E. (2004). Capital structure in the world airline industry. Transportation Research Part A: Policy and Practice, 38(6), 421-434. https://doi.org/10.1016/j.tra.2004.03.002

Carter, D. A., Rogers, D. A., \& Simkins, B. J. (2003). Does fuel hedging make economic sense? The case of the US Airline Industry. AFA 2004 San Diego Meetings (September 16, 2002). https://doi.org/10.2139/ssrn.325402

Chin, A. T. H. \& Tay, J. H. (2001). Developments in air transport: implications on investment decisions, profitability and survival of Asian airlines. Journal of Air Transport Management, 7(5), 319-330. https://doi.org/10.1016/S0969-6997(01)00026-6 de Neufville, R. (2008). Low-cost airports for low-cost airlines: Flexible design to manage the risks. Transportation Planning and Technology, 31(1), 35-68.

https://doi.org/10.1080/03081060701835688

Dobruszkes, F. (2006). An analysis of European low-cost airlines and their networks. Journal of Transport Geography, 14(4), 249-264. https://doi.org/10.1016/j.jtrangeo.2005.08.005

Doganis, R. (2001). Airline business in the 21st century. Routledge, London. https://doi.org/10.4324/9780203991916

European Cockpit Association. (2006). Upheaval in the European skies. Low cost carriers in Europe: economic data, market and pilot demand forecast. ECA Industrial Sub Group, June 2006. Brussels, Belgium. https://www.eurocockpit.be/sites/ default/files/LCC-Book-2006-Final-Web.pdf

Fariñas, J. C., Calvo, J. L., Jaumandreu, J. M., Lorenzo, M. J., Huergo, E., \& De la Iglesia, C. (1992). La Pyme industrial en España. Civitas, Madrid. https://e-archivo.uc3m.es/handle/10016/5269

Fernandes, E., \& Capobianco, H. M. P. (2001). Airline capital structure and returns. Journal of Air Transport Management, 7(3), 137-142. https://doi.org/10.1016/S0969-6997(00)00041-7

Galve, C., \& Salas, V. (1993). Propiedad y resultados de la gran empresa española. Investigaciones Económicas, 17(2), 207238. https://www.fundacionsepi.es/investigacion/revistas/paperArchive/May1993/v17i2a1.pdf

Gillen, D., \& Lall, A. (2004). Competitive advantage of low-cost carriers: some implications for airports. Journal of Air Transport Management, 10(1), 41-50.

https://doi.org/10.1016/j.jairtraman.2003.10.009

Ginieis, M., Sánchez-Rebull, M. V., \& Campa-Planas, F. (2012). The academic journal literature on air transport: Analysis using systematic literature review methodology. Journal of Air Transport Management, 19, 31-35. https://doi.org/10.1016/j.jairtraman.2011.12.005

Ginieis, M., Sánchez-Rebull, M. V., \& Campa-Planas, F. (2013). Relationship between type of airline and wage of pilots in Europe. Aviation, 17(1), 33-43. https://doi.org/10.3846/16487788.2013.774940

González, A., \& Correa, A. (1998). Crecimiento y tamaño, un estudio empírico. Revista Española de Financiación y Contabilidad, 27(95), 541-573. https://www.jstor.org/stable/42782143

Graf, L. (2005). Incompatibilities of the low-cost and network carrier business models within the same airline grouping. Journal of Air Transport Management, 11(5), 313-327. https://doi.org/10.1016/j.jairtraman.2005.07.003

Greer, M. R. (2008). Nothing focuses the mind on productivity quite like the fear of liquidation: Changes in airline productivity in the United States, 2000-2004. Transportation Research Part A: Policy and Practice, 42(2), 414-426. https://doi.org/10.1016/j.tra.2007.11.001

Gudmundsson, S. V. (2004). Management emphasis and performance in the airline industry: An exploratory multilevel analysis. Transportation Research Part E: Logistics and Transportation Review, 40(6), 443-463. https://doi.org/10.1016/j.tre.2004.08.004

Halpern, N. (2008). Lapland's airports: Facilitating the development of international tourism in a peripheral region. Scandinavian Journal of Hospitality and Tourism, 8(1), 25-47. https://doi.org/10.1080/15022250801987762

Hansen, M. M., Gillen, D., \& Djafarian-Tehrani, R. (2001). Aviation infrastructure performance and airline cost: a statistical cost estimation approach. Transportation Research Part E: Logistics and Transportation Review, 37(1), 1-23. https://doi.org/10.1016/S1366-5545(00)00008-9 
Heracleous, L., \& Wirtz, J. (2009). Strategy and organization at Singapore airlines: achieving sustainable advantage through dual strategy. Journal of Air Transport Management, 15(6), 274-279. https://doi.org/10.1016/j.jairtraman.2008.11.011

Hernández, A. B., Campa-Planas, F., \& Sánchez-Rebull, M. V. (2012). Categorizing the Spanish accommodation sector: does firm size influence economic profitability? Cornell Hospitality Quarterly, 53(3), 257-264.

https://doi.org/10.1177/1938965512445459

Heshmati, A., \& Kim, J. (2016). Efficiency and competitiveness of international airlines. Springer.

https://doi.org/10.1007/978-981-10-1017-0

IATA. (2016). Economic performance of the airline industry. International Air Transport Association (IATA). Report, June 2016. https://www.iata.org/whatwedo/Documents/economics/IATA-Economic-Performance-of-the-Industry-end-year2016-report.pdf

Jakšić, D., Mijić, K., \& Andrić, M. (2012). Analysis of variations in the performance of audit firms in the republic of Serbia. Economic Annals, 57(193), 71-91. https://ideas.repec.org/a/ beo/journl/v57y2012i193p71-92.html

Kalemba, N., \& Campa-Planas, F. (2019). Safety and the economic and financial performance in the airline industry: Is there any relationship? Aviation, 23(1), 7-14.

https://doi.org/10.3846/aviation.2019.9744

Klophaus, R. (2005). Frequent flyer programs for European lowcost airlines: Prospects, risks and implementation guidelines. Journal of Air Transport Management, 11(5), 348-353. https://doi.org/10.1016/j.jairtraman.2005.07.001

Lee, C. H., \& Hooy, C. W. (2012). Determinants of systematic financial risk exposures of airlines in North America, Europe and Asia. Journal of Air Transport Management, 24, 31-35. https://doi.org/10.1016/j.jairtraman.2012.06.003

Link, H., Götze, W., \& Himanen, V. (2009). Estimating the marginal costs of airport operation using multivariate time series models with correlated error terms. Journal of Air Transport Management, 15(1), 41-46.

https://doi.org/10.1016/j.jairtraman.2008.07.003

Lopes, I. T, Ferraz, D. P., \& Gomes Rodrigues, A. M. (2016). The drivers of profitability in the top 30 major airlines worldwide. Measuring Business Excellence, 20(2), 26-37. https://doi.org/10.1108/MBE-09-2015-0045

Maenhout, B., \& Vanhoucke, M. (2011). Days on and days off scheduling of pilots under a variable workload. In C. R. Walsh (Ed.), Airline industry: strategies, operations and safety (pp. 193-212). Nova Science Publishers, Inc. https://ideas.repec.org/p/rug/rugwps/11-755.html

Mantin, B. \& Wang, J. H. E. (2012). Determinants of profitability and recovery from system-wide shocks: The case of the airline industry. Journal of Airline and Airport Management, 2(1), 1-33. https://doi.org/10.3926/jairm.2

Mason, K. J. (2000). The propensity of business travellers to use low cost airlines. Journal of Transport Geography, 8(2), 107119. https://doi.org/10.1016/S0966-6923(99)00032-0

Melo Filho, C. R., Salgado, L. H., Sato, R., \& Oliveira, A. V. M. (2014). Modeling the effects of wage premiums on airline competition under asymmetric economies of density: A case study from Brazil. Journal of Air Transport Management, 36, 59-68. https://doi.org/10.1016/j.jairtraman.2013.12.010

Merkert R., \& Pearson J. (2015). A non-parametric efficiency measure incorporating perceived airline service levels and profitability. Journal of Transport Economics and Policy, 49(2), 261-275. https://www.ingentaconnect.com/contentone/lse/ jtep/2015/00000049/00000002/art00006
Mohammadi-Amin, M., \& Karimi, N. (2018). General aviation in Iran - challenges and opportunities. International Journal of Engineering and Technology (UAE), 7(4), 190-194. https:// webcache.googleusercontent.com/search?q=cache:4f8ogHAn ySYJ:https://www.sciencepubco.com/index.php/ijet/article/do wnload $/ 22423 / 11014+\& c d=11 \&$ hl $=$ es \&ct $=$ clnk\&gl=es

Morrell, P. (2005). Airlines within airlines: An analysis of US network airline responses to Low Cost Carriers. Journal of Air Transport Management, 11(5), 303-312. https://doi.org/10.1016/j.jairtraman.2005.07.002

Najda, C. (2003). Low-Cost carriers and low fares: competition and concentration in the U.S. airline industry. Department of Economics, Stanford University, May 2003, USA. http://ftp.zew.de/pub/zew-docs/dp/dp11051.pdf

Neal, Z. P., \& Kassens-Noor, E. (2011). The business passenger niche: Comparing legacy carriers and southwest during a national recession. Journal of Air Transport Management, 17(4), 231-232. https://doi.org/10.1016/j.jairtraman.2010.09.001

Novak, A., Havel, K., \& Adamko, P. (2019). Number of conflicts at the route intersection - minimum distance model. Aviation, 23(1), 1-6. https://doi.org/10.3846/aviation.2019.9746

Oleshko, T., \& Heiets, I. (2018). Perspectives of the air transportation market in Ukraine. Aviation, 22, 1-5. https://doi.org/10.3846/aviation.2018.1855

Oum, T. H., Fu, X., \& Yu, C. (2005). New evidences on airline efficiency and yields: A comparative analysis of major North American air carriers and its implications. Transport Policy, 12(2), 153-164. https://doi.org/10.1016/j.tranpol.2005.01.002

Oum, T. H., Park, J. H., Kim, K., \& Yu, C. (2004). The effect of horizontal alliances on firm productivity and profitability: evidence from the global airline industry. Journal of Business Research, 57, 844-853. https://doi.org/10.1016/S0148-2963(02)00484-8

Oum, T. H., \& Yu, C. (1995). A productivity comparison of the world's major airlines. Journal of Air Transport Management, 2(3/4), 181-195. https://doi.org/10.1016/0969-6997(96)00007-5

Oum, T. H., \& Yu, C. (1998). An analysis of profitability of the world's major airlines. Journal of Air Transport Management, 4(4), 229-237. https://doi.org/10.1016/S0969-6997(98)00023-4

Pantazis, N., \& Liefner, I. (2006). The impact of low-cost carriers on catchment areas of established international airports: The case of Hanover Airport, Germany. Journal of Transport Geography, 14(4), 265-272. https://doi.org/10.1016/j.jtrangeo.2005.05.002

Parast, M. M., \& Fini, E. H. (2010). The effect of productivity and quality on profitability in US airline industry: An empirical investigation. Managing Service Quality, 20(5), 458-474. https://doi.org/10.1108/09604521011073740

Randøy, T., \& Strandenes, S. P. (1997). The effect of public ownership and deregulation in the Scandinavian airline industry. Journal of Air Transport Management, 3(4), 211-215. https://doi.org/10.1016/S0969-6997(97)00028-8

Reynolds-Feighan, A. (2001). Air-freight logistics. In A. M. Brewer, K. J. Button, \& D. A. Hensher (Eds.), Handbook of logistics and supply-chain management. Elsevier Science Ltd., UK. https://ideas.repec.org/p/ucn/oapubs/10197-99.html

Rumelt, R. (1991). How much does industry matter? Strategic Management Journal, 12(3), 167-185. https://doi.org/10.1002/smj.4250120302

Santana, I. (2009). Do public service obligations hamper the cost competitiveness of regional airlines? Journal of Air Transport Management, 15(6), 344-349.

https://doi.org/10.1016/j.jairtraman.2008.12.001

Shen, Y. (2017). Market competition and market price: Evidence from United/Continental airline merger. Economics of Transportation, 10, 1-7. https://doi.org/10.1016/j.ecotra.2017.03.001 
Schmalensee, R. (1985). Do markets differ much? American Economic Review, 75(3), 341-351.

https://www.jstor.org/stable/1814804

Sjögren, S., \& Söderberg, M. (2011). Productivity of airline carriers and its relation to deregulation, privatisation and membership in strategic alliances. Transportation Research Part E: Logistics and Transportation Review, 47(2), 228-237. https://doi.org/10.1016/j.tre.2010.09.001

Soria-Baledón, M., \& Kosoy, N. (2018). "Problematizing” carbon emissions from international aviation and the role of alternative jet fuels in meeting ICAO"s mid-century aspirational goals. Journal of Air Transport Management, 71, 130-137. https://doi.org/10.1016/j.jairtraman.2018.06.001

Srisaeng, P., Baxter, G. S., \& Wild, G. (2014). The evolution of low cost carriers in Australia. Aviation 18(4), 203-216. https://doi.org/10.3846/16487788.2014.987485

Stierwald, A. (2010). Determinants of profitability: An analysis of large Australian firms. The University of Melbourne. Melbourne Institute Working Papers Series. Working Paper 3/10, Melbourne. https://econpapers.repec.org/paper/iaeiaewps/ wp2010n03.htm
Tesfay, Y. Y. (2016a). Modified panel data regression model and its applications to the airline industry: Modeling the load factor of Europe North and Europe Mid Atlantic flights. Journal of Traffic and Transportation Engineering (English Edition), 3(4), 283-295. https://www.sciencedirect.com/science/article/ pii/S2095756415306498

Tesfay, Y. Y. (2016b). Stochastic evaluation of capacity and demand management of the airline industry: the case of airlines of the AEA for flights of Europe-Africa. International Journal of Applied Management Sciences and Engineering (IJAMSE), 3(2), 1-20. https://www.igi-global.com/article/stochastic-evaluation-of-capacity-and-demand-management-of-the-airline-industry/173464

Tesfay, Y. Y., \& Solibakke, P. B. (2015). Spectral density estimation of European airlines load factors for Europe-Middle East and Europe-Far East flights. European Transport Research Review, 7(2), 14 https://doi.org/10.1007/s12544-015-0162-8

Tretheway, M. (2011). Comment on "legacy carriers fight back". Journal of Air Transport Management, 17(1), 40-43. https://doi.org/10.1016/j.jairtraman.2010.10.009

Tsoulakas, G., Belobaba, P., \& Swelbar, W. (2008). Cost convergence in the US airline industry: An analysis of unit costs 1995-2006. Journal of Air Transport Management, 14(4), 179187. https://doi.org/10.1016/j.jairtraman.2008.04.005 